Instructions for authors, subscriptions and further details:

http://ijep.hipatiapress.com

\title{
List of 2017 Reviewers
}

Date of publication: February $24^{\text {th }}, 2018$

Edition period: February 2018 - June 2018

To cite this article: IJEP Editors (2018). List of Reviewers. International Journal of Educational Psychology, 7(1), 93. doi: 10.17583/ijep.2018.3327

To link this article: http://dx.doi.org/10.17583/ijep.2018.3327

\section{PLEASE SCROLL DOWN FOR ARTICLE}

The terms and conditions of use are related to the Open Journal System and to Creative Commons Attribution License (CC-BY). 
IJEP - International Journal of Educational Psychology, Vol. 7 No. 1 February 2018 pp. 93

\section{List of 2017 Reviewers}

We thank the individuals who were reviewers for the International Journal of Educational Psychology over the year 2017. We deeply appreciate their contributions to the quality of the journal.

Sandra Racionero-Plaza

Rocío García-Carrión

Editors

Icy Anabo

Silvia Molina

Elisenda Giner

Jordi Cano

Ana Vidu

Tinka Schubert

Lirio Flores

Itxaso Tellado

Joana Lucio

Oriol Ríos

Sergio Fernández Artamendi

Montse Vela

Andrea Khalfaoui

Liria Fernández

Carmen Martín

Nagore Navarrete

Mihir Dash

Laura Bermejo

Heidi Sairanen

Pilar Álvarez
Walfredo González

Javier Díez 